\title{
Experimental Study of Gas-Liquid Two-Phase Flow for High Velocity in Inclined Medium Size Tube and Verification of Pressure Calculation Methods
}

\author{
Wei Luo ${ }^{1 *, 2}$, Yong $\mathrm{Li}^{3}$, Wang Qinghua ${ }^{4}$, Junliang Li ${ }^{1,2}$, Ruiquan Liao ${ }^{1,2}$ and Zilong Liu 1,2 \\ ${ }^{1}$ Yangtze University, Wuhan, Hubei 430100, China \\ 2 The Branch of Key Laboratory of CNPC for Oil and Gas Production, Yangtze University, \\ Jingzhou 434023, China \\ ${ }^{3}$ Research and Development Center, Tuha Oilfield Company, PetroChina, Hami 839009, China \\ ${ }^{4}$ Langfang Branch, PetroChina Research Institute of Exploration and Development, Langfang \\ 065007, China
}

Email: luoruichang@163.com

\begin{abstract}
In view of the limited conditions of the previous inclined multiphase pipe flow experiments (diameter and flow) with no reliable adaptability of multiphase pipe flow calculation method which is obtained from this experimental conditions when the using conditions are beyond the scope of the experiment (such as a middle to large diameter and large flow), the gas-liquid two-phase flow experiment was carried out using air and water as the medium with different inclined angles $0^{\circ}, 15^{\circ}, 30^{\circ}, 45^{\circ}, 60^{\circ}, 75^{\circ}$ and $90^{\circ}$ in this paper. The analysis of variation of liquid holdup and pressure drop with different gas and liquid quantities and inclination angles was obtained. The calculation method applicability of liquid holdup and pressure drop were verified and selected from the experimental data, and the error variation law of the calculation methods were analysed. The applicability of the calculation method was compared with its applicability to liquid holdup and pressure drop as verified by the field test data. According to the analysis of the comparative results, the applicability conditions of the existing pressure calculation methods were obtained and they provided the guidance for the selection of the inclined multiphase pipe flow calculation methods under the condition of middle and high production rates.
\end{abstract}

Keywords: Inclined multiphase pipe flow, Calculation method applicability, Liquid holdup, Pressure drop, Pressure calculation methods.

\section{INTRODUCTION}

Although the research of multiphase pipe flow has lasted for more than half a century, so far there is no general inclined wellbore multiphase pipe flow pressure prediction model. The current multiphase pipe flow pressure calculation methods still have some imperfections respectively: (1) So far, the research of multiphase pipe flow pressure calculation method has mainly concentrated on the horizontal and vertical tubes [1-9]; (2) The existing multiphase pipe flow pressure calculation methods have mostly been empirical and semi empirical methods and are obtained within a certain range of experiments which mainly focus on the small and middle flow rate conditions. The resulting accuracy is not reliable beyond this scope.

The Beggs \& Brill method [10][11] is a more complete pressure calculation method which is based on the experimental study of multiphase flow in an inclined tube, but the experimental tubes are only in $25.4 \mathrm{~mm}$ and $38.1 \mathrm{~mm}$. Although S. L. KOKAL et al. [12] carried out an oil and gas two-phase study in the larger diameter $51.2 \mathrm{~mm}$ and $76.3 \mathrm{~mm}$, it was using a small inclination angle. Jing Wang et al. [13] also carried out a gas oil two-phase flow study in a pipe with a diameter of $125 \mathrm{~mm}$ with less than 15 degree inclined angle. J. Y. Cai et al. [14] carried out an oil gas water three-phase flow study using a $100 \mathrm{~mm}$ diameter pipe which also used a small angle. G. Oddie et al. [15] carried out an oil and gas two-phase study, an oil gas water three-phase flow study and other studies using a $150 \mathrm{~mm}$ diameter pipe for inclined multiphase pipe flow. Perez V H [16] conducted a study of two-phase flow in inclined pipes, but the superficial velocities ranged from 0.15 to $8.9 \mathrm{~m} / \mathrm{s}$ for air and from $0.04 \mathrm{~m} / \mathrm{s}$ to 0.7 $\mathrm{m} / \mathrm{s}$ for water. It is known that the inclined gas-liquid twophase flow study for high velocity in the medium size diameter $(50-80 \mathrm{~mm})$ has still not been done.

Predicting slant borehole pressure drop accurately is the foundation of natural flow production prediction, optimization design of artificial lift parameters and making appropriate working rules, and also plays an important role in oil and gas gathering and transportation. In view of this, it is 
necessary to carry out a multiphase pipe flow experimental study at high velocity with different inclined angles in medium size tube and verify existing calculation methods to grasp the inclined pipes gas-liquid two-phase flow law of high velocity and its calculation methods. This would have important guiding significance to develop highly efficient oilfields.

\section{EXPERIMENTAL DEVICES AND RANGE}

The experiment was done in Yangtze University multiphase flow experimental platform [17], and it is shown in Figure 1. The experimental system consists of gas supply system, liquid supply system, data acquisition system, the test tube and a gas-liquid separator system and its supporting pipeline. Liquid passed through the liquid booster pump, regulator, filter, was measured and then mixed with compressed gas in the test tube section, It finally passed through the gas-liquid separator back into the oil-water mixing tank after dissociating gas, and liquid was recycled.



Figure 1. The multiphase pipe flow laboratory

The experiment of gas-liquid two-phase flow was done at room temperature with different incline angles of $0^{\circ}, 15^{\circ}, 30^{\circ}$, $45^{\circ}, 60^{\circ}, 75^{\circ}$ and $90^{\circ}$. The experimental medium is water and air. The experimental diameter is DN60. The range of gas flow rate is $5000 \sim 48000 \mathrm{~m}^{3} / \mathrm{d}$. The range of superficial gas velocity (subsequently referred to as "gas velocity") is $20.47 \sim 196.5 \mathrm{~m} / \mathrm{s}$. The range of liquid flow rate is $50 \sim 480 \mathrm{~m}^{3} / \mathrm{d}$ and the range of liquid superficial velocity (subsequently referred to as "liquid velocity") is $0.205 \sim 1.965 \mathrm{~m} / \mathrm{s}$. The range of experimental operation pressure is $0 \sim 1 \mathrm{MPa}$. Pressure, differential pressure, temperature and other parameters can be measured directly in the experiment using different types of online sensors, and these data are saved to the database system and was collected by a centralized console control data acquisition system. The liquid holdup parameter of the test tube was measured indirectly through the quick closing valves. The flow pattern of the test tube was assessed by combining both measurements of the high-speed video camera and observation of the experimenter. The experimental process is shown in Figure 2.

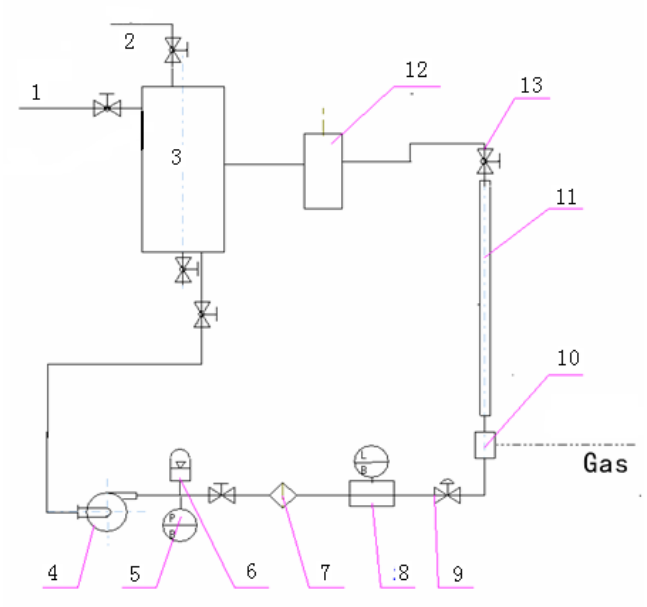

1 flow entrance of oil, 2 flow entrance of water, 3 oil-water mixer, 4 liquid pump, 5 pressure meter, 6 regulator, 7 moisture content tester, 8 flow meter, 9 adjusting pressure valve, 10 gas-liquid mixer, 11 test tube section, 12 gasliquid separator, 13 valves

Figure 2. Design of the experiment

\section{EXPERIMENTAL DATA ANALYSIS}

\subsection{The variation law of liquid holdup and pressure drop with different gas and liquid velocities}

According to the same basic variation law of liquid holdup and pressure drop with different gas and liquid flow rate between the incline angle $15^{\circ}$ and the incline angle of $0^{\circ}, 30^{\circ}$, $45^{\circ}, 60^{\circ}, 75^{\circ}$ and $90^{\circ}$, the angle of $15^{\circ}$ is used as an example to analyze the variation law of liquid holdup and pressure drop with different gas and liquid flow rates.

Figure 3 is the variation curve of liquid holdup with different gas flow velocities at the same gas liquid flow velocity at the angle of $15^{\circ}$. It can be seen from the chart, at the same liquid flow velocity condition, liquid holdup decreased as the gas flow velocity increased. In the small gas flow velocity, liquid holdup decreased faster as the gas flow velocity increased. Liquid holdup decreased slowly when the gas flow velocity increased to a certain value, and liquid holdup tended to be stable. This is due to the fact that the flow pattern is slug flow in the low gas flow rate. Liquid holdup is larger as the increase of gas flow velocity increased. The low pattern changed from slug flow to churn flow and annular flow. At this time, the liquid rate fell faster. When the flow pattern changed into annular flow, the liquid film thickness of the pipe wall has little change as the gas flow velocity increased. At this time, the liquid holdup decreased more slowly. 


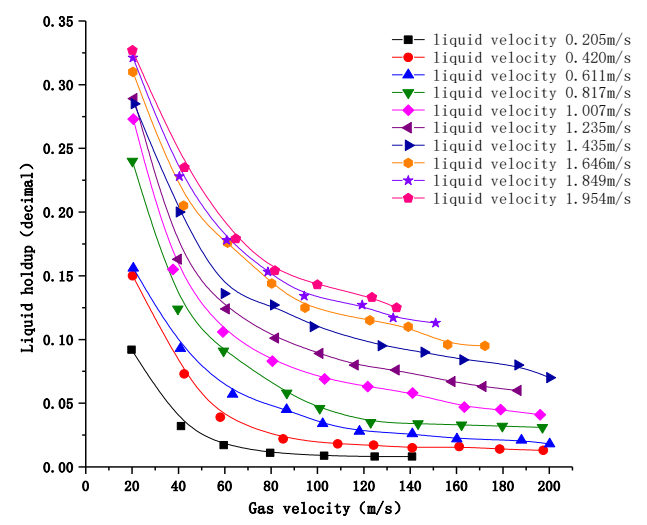

Figure 3. Variation of liquid holdup at the same liquid velocity and different gas velocities at 15 degrees

Figure 4 is the variation curve of liquid holdup with different liquid flow velocities at the same gas flow velocity at the angle of $15^{\circ}$. The chart shows that at the same liquid flow velocity condition, liquid holdup increased as the liquid flow velocity increased.

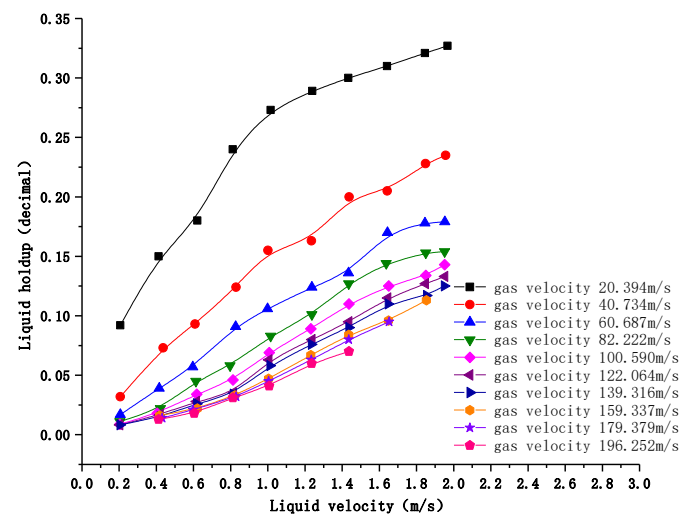

Figure 4. Variation of liquid holdup at the same gas velocity and different liquid velocities at 15 degrees

Figure 5 is the variation curve of pressure drop with different gas flow velocities at the same gas liquid flow velocity at the angle of $15^{\circ}$. The chart shows that at the same liquid flow velocity condition, when liquid velocity is larger $(1.228 \sim 1.965 \mathrm{~m} / \mathrm{s})$, pressure drop increased quickly at first as the gas flow velocity increased and then increased slowly. In the small liquid flow velocity $(0.205 \sim 1.023 \mathrm{~m} / \mathrm{s})$, pressure drop increased slowly at first as the gas flow velocity increased, or it decreased slightly and then increased quickly.

Figure 6 shows the variation curve of pressure drop with different liquid flow velocities at the same gas flow velocity at the angle of $15^{\circ}$. The chart shows that at the same gas flow velocity condition, pressure drop increased as the liquid flow velocity increased.

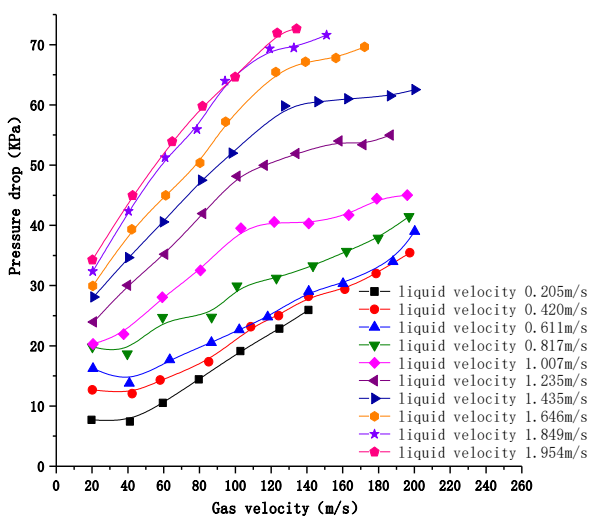

Figure 5. Variation of pressure drop at the same liquid velocity and different gas velocities at 15 degrees

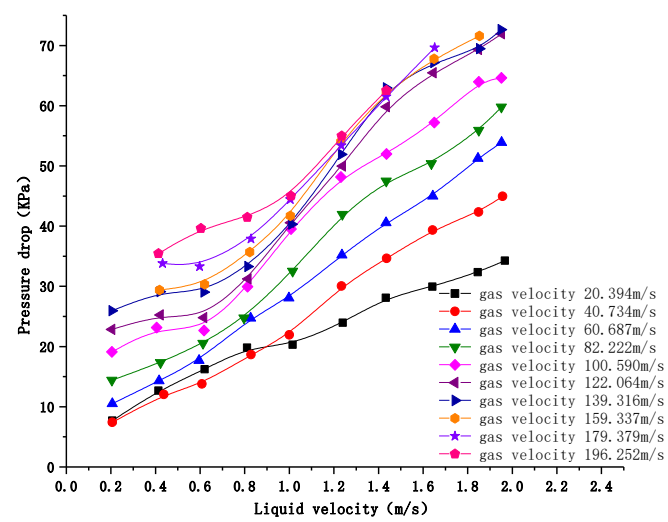

Figure 6. Variation of pressure drop at the same gas velocity and different liquid velocities at 15 degrees

\subsection{Liquid holdup and pressure drop variation with different angles}

When the liquid velocity is $0.205 \mathrm{~m} / \mathrm{s}, 0.420 \mathrm{~m} / \mathrm{s}, 0.611 \mathrm{~m} / \mathrm{s}$, $0.817 \mathrm{~m} / \mathrm{s}, 1.007 \mathrm{~m} / \mathrm{s}, 1.235 \mathrm{~m} / \mathrm{s}, 1.435 \mathrm{~m} / \mathrm{s}, 1.646 \mathrm{~m} / \mathrm{s}$, and $1.954 \mathrm{~m} / \mathrm{s} 1.849 \mathrm{~m} / \mathrm{s}$, at the same gas flow velocity condition, liquid holdup and pressure drop had the same variation law as the inclined angle increased. Therefore, a high production rate (liquid velocity range for $1.007 \mathrm{~m} / \mathrm{s}-1.954 \mathrm{~m} / \mathrm{s}$ ) is used as an example to analyze the variation law of liquid holdup and pressure drop with different inclined angles.

At the same gas and liquid velocity, liquid holdup and pressure drop changed with the inclined angle. At a certain liquid flow velocity, Figure 7 is respectively liquid holdup curve at different inclined angles at the same gas flow velocity. It can be seen from the charts, liquid holdup increased at first on the whole as the inclined angle increased, and then had a decreasing trend, and liquid holdup is largest in the angle range of $30^{\circ}$ to $60^{\circ}$.

At a certain liquid flow velocity, Figure 8 is respectively pressure drop curve at different inclined angles at the same gas flow velocity. It can be seen from the charts, pressure drop increased the fastest in the angle range of $30^{\circ}$ to $60^{\circ}$, and it is in agreement with the liquid holdup variation law as the inclined angle increased. 

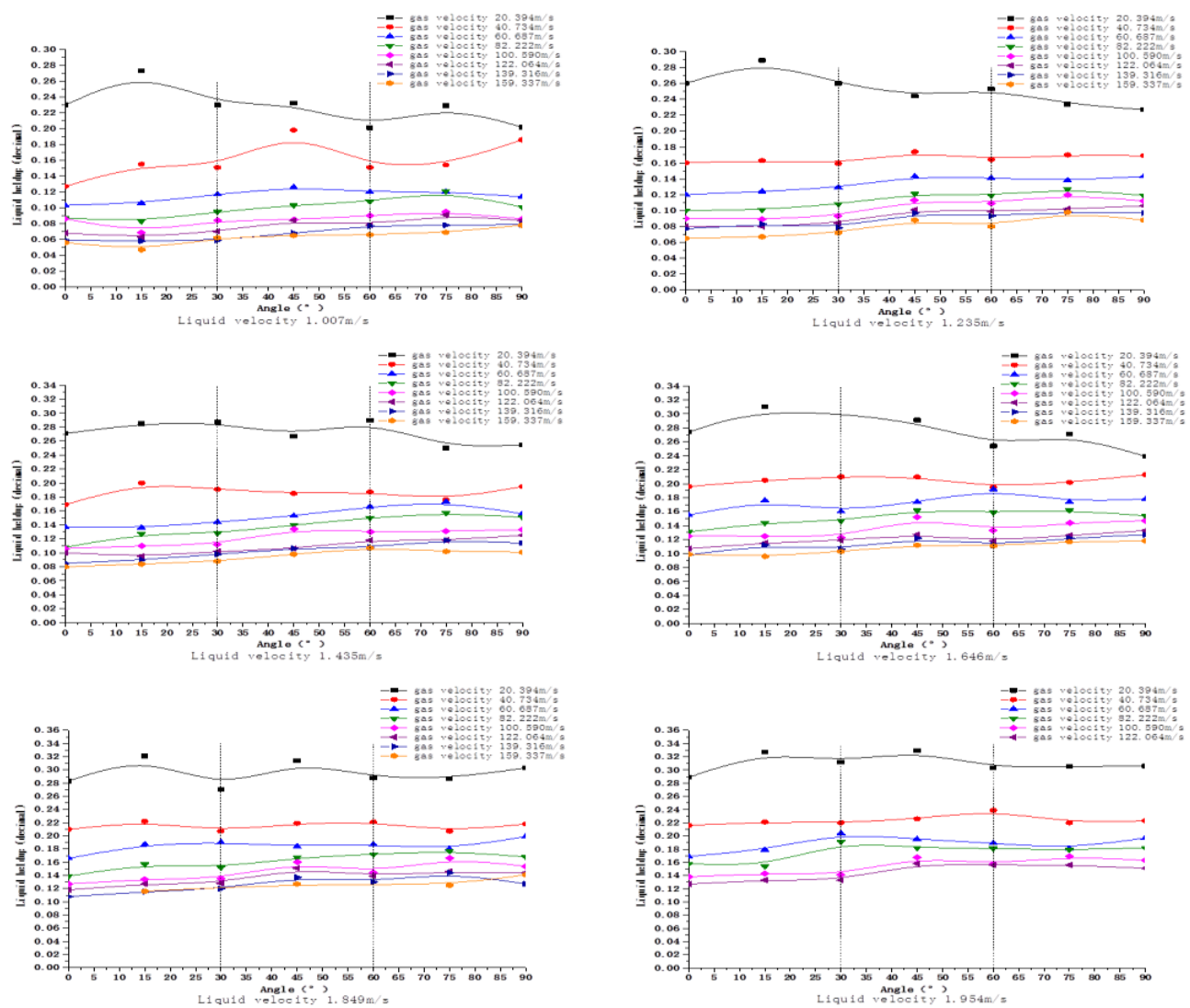

Figure 7. Liquid holdup variation curves at different inclined angles at the same gas and liquid flow velocity


Figure 8. Pressure drop variation curves at different inclined angles at the same gas and liquid flow velocity 


\section{VALIDATION OF MULTIPHASE FLOW PRESSURE CALCULATION METHODS UNDER THE CONDITION OF HIGH PRODUCTION RATE IN MEDIUM SIZE TUBE}

Accurate prediction of inclined wellbore pressure drop is the foundation of the natural flow production prediction, artificial lift production prediction and parameters optimization design. Although the research of multiphase flow in the wellbore has been continuing for quite some time, there are many various kinds of methods in the multiphase pipe flow pressure calculation: Dun-Ros [1], HagedornBrown [2], Orkiszewski [3], Aziz-Govier-Fogarasi [4], Taitel-Bornea-Dukler [5], Hasan-Kabir [6], JPI [7], BeggsBrill [10][11], Mukherjee-Brill [18], Ansari [19], Hong-Quan Zhang [20], etc. However, most of them are obtained in vertical tube experiments, and there is little research on multiphase pipe flow pressure calculation methods that can be used for different inclined angles. Beggs-Brill [10][11] and Brill-Mukherjee [18] are two kinds of methods that are currently recognized. In addition, another approach for inclined wellbore pressure calculation is the inclined angle correction methods that were used to calculate vertical wellbore pressure. These inclined angle correction methods can be used for pressure calculation of inclined natural flow and gas lift wells, etc. after having been revised.

For the vertical wellbore multiphase flow, the equations are as follows:

$$
\left(\frac{d p}{d z}\right)_{\text {total }}=\left(\frac{d p}{d z}\right)_{\text {gravity }}+\left(\frac{d p}{d z}\right)_{\text {friction }}+\left(\frac{d p}{d z}\right)_{\text {acceleration }}
$$

In pressure drop calculation of inclined pipe, the item of gravity pressure drop should be revised by using an inclined angle. So the item of gravity pressure drop is calculated by vertical depth and the items of frictional and accelerating pressure drop are calculated by using the actual length.

Therefore, a common vertical wellbore multiphase flow pressure calculation method is chosen to be revised as a representative for the inclined wellbore pressure prediction, and the selection method is Orkiszewski. In this way, finally, there are three kinds of inclined wellbore multiphase pipe flow pressure calculation methods used for validation and error law analysis of methods: Beggs Brill modified, Mukherjee-Brill and Orkiszewski. Which method will be chose should be determined by field test data.

Firstly, the calculation methods of liquid holdup and pressure drop are compiled respectively by using VB language, then both the experiment data and the field measured data were tested respectively as follows;

(1) Several pressure calculation methods (Beggs Brill modified, Mukherjee-Brill and Orkiszewski) and liquid holdup calculation methods (Beggs Brill modified and Mukherjee-Brill) have been validated by using experiment data of gas-liquid two-phase flow to analyse the experimental application applicability of liquid holdup calculation methods and pressure drop calculation methods, as shown in Tables 1 and 2.

Table 1 shows that when the inclination angle is less than or equal to $45^{\circ}$ and the production rate is less than or equal to $200 \mathrm{~m}^{3} / \mathrm{d}$, the liquid holdup calculation error of Beggs Brill revised is greater than that of Brill-Mukherjee, so the liquid holdup calculation method of Brill-Mukherjee is more accurate in these conditions. In the other remaining conditions, the liquid holdup calculation error of Beggs Brill revised is less than that of Brill-Mukherjee, so the Beggs Brill revised liquid holdup calculation method is more accurate, with less calculation error. As can be seen from the liquid holdup calculation error of Beggs Brill revised, the liquid holdup calculation error decreases as the production rate increases. At the same time, the liquid holdup calculation error decreases as the inclined angle increases.

It can be seen from Table 2, among three kinds of calculation methods, the average calculation error of Beggs Brill revised pressure drop calculation method is lowest. Average calculation error of three pressure drop calculation methods mostly had a decreasing trend as the the inclined angle increased. At the same time, most average calculation error of the three pressure drop calculation methods showed a decreasing trend as the production rate increased. Furthermore, in the range of experimental production rate (less than $500 \mathrm{~m}^{3} / \mathrm{d}$ ), pressure drop prediction results of Beggs Brill revised method changed from larger to smaller than experimental data as production rate increased. The prediction results of the Brill-Mukherjee pressure drop calculation method is always larger than experimental data and the error gradually becomes smaller as the production rate increases. The prediction results of the Orkiszewski pressure drop calculation method is always smaller than experimental data and the absolute error gradually becomes smaller as the production rate increases.

(2) Several pressure calculation methods (Beggs Brill advised, Mukherjee-Brill and Orkiszewski) were verified by measured test data of four high oil production rate wells in two overseas oilfields. The applicability of field application of the pressure drop calculation methods was analysed. The basic data and the test data of four wells are shown in Tables 3 to 10 , and the calculated results are shown in Figures 9 to 12.

(1)Basic data and measured data of X1 well in oilfield A are given in Tables 3 and 4 .

From Figures 9 to 12 , it can be seen that the production rate range of the tested data is $251.19 \mathrm{~m}^{3} / \mathrm{d}$ to $688.87 \mathrm{~m}^{3} / \mathrm{d}$. The maximum production rate is greater than the maximum liquid rate in experiment. The order of size of prediction results of three kinds of multiphase flow pressure calculation methods using the oilfield measured parameters is mostly the same as the order of size of prediction results of these methods using the experimental parameters. Prediction results of three kinds of multiphase flow pressure prediction methods using the oilfield measured parameters were all smaller than the oilfield measured data, and their prediction error is the same as the trend of prediction error of three kinds of calculation methods using experimental parameters, the trend is that prediction error decreases and pressure drop prediction results changed from larger to smaller than experimental data as the production rate increased.

(2)Basic data and measured data of X2 well in A oilfield are given in Tables 5 and 6 .

(3) Basic data and measured data of X3 well in A oilfield are given in Tables 7 and 8 .

(4) Basic data and measured data of X4 well in B oilfield are given in Tables 9 and 10 . 
Table 1. Applicability verification results of two kinds of liquid holdup calculation models

\begin{tabular}{|c|c|c|c|c|c|c|c|c|c|c|c|}
\hline \multirow{3}{*}{ Method } & \multirow{3}{*}{$\begin{array}{l}\text { Angle } \\
\left({ }^{\circ}\right)\end{array}$} & \multicolumn{10}{|c|}{ Range of liquid production rate $\left(\mathrm{m}^{3} / \mathrm{d}\right)$} \\
\hline & & \multicolumn{2}{|l|}{$\mathrm{Q}<=100$} & \multicolumn{2}{|c|}{$100<Q<=200$} & \multicolumn{2}{|c|}{$200<Q<=300$} & \multicolumn{2}{|c|}{$300<Q<=400$} & \multicolumn{2}{|l|}{$Q>400$} \\
\hline & & $\begin{array}{l}\text { Average } \\
\text { error }\end{array}$ & $\begin{array}{l}\text { Average } \\
\text { absolute } \\
\text { error }\end{array}$ & $\begin{array}{l}\text { Averag } \\
\text { e error }\end{array}$ & $\begin{array}{l}\text { Average } \\
\text { absolute } \\
\text { error }\end{array}$ & $\begin{array}{l}\text { Average } \\
\text { error }\end{array}$ & $\begin{array}{l}\text { Average } \\
\text { absolute } \\
\text { error }\end{array}$ & $\begin{array}{l}\text { Avera } \\
\text { ge } \\
\text { error }\end{array}$ & $\begin{array}{l}\text { Average } \\
\text { absolute } \\
\text { error }\end{array}$ & $\begin{array}{l}\text { Average } \\
\text { error }\end{array}$ & $\begin{array}{l}\text { Average } \\
\text { absolute } \\
\text { error }\end{array}$ \\
\hline \multirow{7}{*}{$\begin{array}{l}\text { Beggs } \\
\text { Brill }\end{array}$} & 0 & $148.0 \%$ & $154.3 \%$ & $38.6 \%$ & $45.9 \%$ & $18.2 \%$ & $23.7 \%$ & $15.5 \%$ & $18.8 \%$ & $9.3 \%$ & $10.8 \%$ \\
\hline & 15 & $150.9 \%$ & $160.9 \%$ & $55.5 \%$ & $64.4 \%$ & $20.0 \%$ & $28.0 \%$ & $7.5 \%$ & $13.7 \%$ & $6.0 \%$ & $8.0 \%$ \\
\hline & 30 & $121.2 \%$ & $134.0 \%$ & $48.4 \%$ & $56.7 \%$ & $13.7 \%$ & $20.7 \%$ & $7.1 \%$ & $10.9 \%$ & $7.0 \%$ & $10.1 \%$ \\
\hline & 45 & $-10.8 \%$ & $39.8 \%$ & $-6.8 \%$ & $19.5 \%$ & $-4.3 \%$ & $11.2 \%$ & $-1.6 \%$ & $6.0 \%$ & $-3.6 \%$ & $4.3 \%$ \\
\hline & 60 & $-20.7 \%$ & $30.0 \%$ & $1.3 \%$ & $23.5 \%$ & $1.6 \%$ & $9.1 \%$ & $0.8 \%$ & $9.2 \%$ & $1.6 \%$ & $5.6 \%$ \\
\hline & 75 & $-35.6 \%$ & $35.6 \%$ & $-7.0 \%$ & $15.4 \%$ & $-6.7 \%$ & $9.2 \%$ & $-3.4 \%$ & $6.2 \%$ & $-1.0 \%$ & $3.9 \%$ \\
\hline & 90 & $-18.8 \%$ & $22.9 \%$ & $-7.0 \%$ & $11.7 \%$ & $-2.3 \%$ & $6.8 \%$ & $-3.3 \%$ & $7.4 \%$ & $-1.5 \%$ & $5.2 \%$ \\
\hline \multirow{7}{*}{ Mukherjee } & 0 & $-22.2 \%$ & $23.8 \%$ & $-9.1 \%$ & $12.4 \%$ & $14.2 \%$ & $16.9 \%$ & $40.4 \%$ & $40.4 \%$ & $84.1 \%$ & $84.1 \%$ \\
\hline & 15 & $12.1 \%$ & $36.4 \%$ & $24.4 \%$ & $27.4 \%$ & $35.1 \%$ & $35.1 \%$ & $57.1 \%$ & $57.1 \%$ & $84.8 \%$ & $84.8 \%$ \\
\hline & 30 & $7.2 \%$ & $28.8 \%$ & $28.1 \%$ & $30.2 \%$ & $39.4 \%$ & $39.4 \%$ & $63.4 \%$ & $63.4 \%$ & $103.2 \%$ & $103.2 \%$ \\
\hline & 45 & $-31.9 \%$ & $31.9 \%$ & $5.9 \%$ & $12.8 \%$ & $17.1 \%$ & $17.7 \%$ & $55.5 \%$ & $55.5 \%$ & $73.1 \%$ & $73.1 \%$ \\
\hline & 60 & $-34.0 \%$ & $34.0 \%$ & $-1.3 \%$ & $13.2 \%$ & $19.9 \%$ & $21.6 \%$ & $52.5 \%$ & $52.5 \%$ & $78.8 \%$ & $78.8 \%$ \\
\hline & 75 & $-46.6 \%$ & $46.6 \%$ & $-12.2 \%$ & $17.2 \%$ & $5.0 \%$ & $19.7 \%$ & $39.7 \%$ & $39.7 \%$ & $63.7 \%$ & $63.7 \%$ \\
\hline & 90 & $-33.2 \%$ & $33.2 \%$ & $-14.8 \%$ & $21.8 \%$ & $9.1 \%$ & $20.7 \%$ & $36.5 \%$ & $37.5 \%$ & $60.2 \%$ & $60.2 \%$ \\
\hline
\end{tabular}

Table 2. Applicability verification results of three kinds of pressure drop calculation models

\begin{tabular}{|c|c|c|c|c|c|c|c|c|c|c|c|}
\hline \multirow[b]{3}{*}{ Method } & \multirow{3}{*}{$\begin{array}{l}\text { Angle } \\
\left({ }^{\circ}\right)\end{array}$} & \multicolumn{10}{|c|}{ Range of liquid production rate $\left(\mathrm{m}^{3} / \mathrm{d}\right)$} \\
\hline & & \multicolumn{2}{|l|}{$\mathrm{Q}<=100$} & \multicolumn{2}{|c|}{$100<Q<=200$} & \multicolumn{2}{|c|}{$200<Q<=300$} & \multicolumn{2}{|c|}{$300<Q<=400$} & \multicolumn{2}{|l|}{$\mathrm{Q}>400$} \\
\hline & & $\begin{array}{l}\text { Average } \\
\text { error }\end{array}$ & $\begin{array}{l}\text { Average } \\
\text { absolute } \\
\text { error }\end{array}$ & $\begin{array}{l}\text { Average } \\
\text { error }\end{array}$ & $\begin{array}{l}\text { Average } \\
\text { absolute } \\
\text { error }\end{array}$ & $\begin{array}{l}\text { Average } \\
\text { error }\end{array}$ & $\begin{array}{l}\text { Average } \\
\text { absolute } \\
\text { error }\end{array}$ & $\begin{array}{l}\text { Average } \\
\text { error }\end{array}$ & $\begin{array}{l}\text { Average } \\
\text { absolute } \\
\text { error }\end{array}$ & $\begin{array}{l}\text { Average } \\
\text { error }\end{array}$ & $\begin{array}{l}\text { Average } \\
\text { absolute er }\end{array}$ \\
\hline \multirow{7}{*}{ Beggs Brill } & 0 & $53.3 \%$ & $53.3 \%$ & $51.1 \%$ & $51.1 \%$ & $26.2 \%$ & $26.2 \%$ & $24.6 \%$ & $24.6 \%$ & $7.4 \%$ & $7.4 \%$ \\
\hline & 15 & $62.6 \%$ & $68.0 \%$ & $85.5 \%$ & $89.0 \%$ & $37.5 \%$ & $38.6 \%$ & $14.5 \%$ & $16.3 \%$ & $4.0 \%$ & $6.4 \%$ \\
\hline & 30 & $46.1 \%$ & $53.7 \%$ & $78.5 \%$ & $82.9 \%$ & $24.6 \%$ & $28.6 \%$ & $9.8 \%$ & $14.3 \%$ & $-2.5 \%$ & $5.1 \%$ \\
\hline & 45 & $50.7 \%$ & $73.0 \%$ & $49.5 \%$ & $58.2 \%$ & $29.4 \%$ & $34.1 \%$ & $8.4 \%$ & $13.1 \%$ & $0.1 \%$ & $6.4 \%$ \\
\hline & 60 & $21.0 \%$ & $39.4 \%$ & $29.3 \%$ & $38.2 \%$ & $12.8 \%$ & $20.7 \%$ & $2.6 \%$ & $13.1 \%$ & $-5.4 \%$ & $9.4 \%$ \\
\hline & 75 & $21.1 \%$ & $44.8 \%$ & $30.6 \%$ & $39.7 \%$ & $9.1 \%$ & $18.3 \%$ & $-1.9 \%$ & $8.3 \%$ & $-2.4 \%$ & $5.5 \%$ \\
\hline & 90 & $13.8 \%$ & $31.7 \%$ & $23.0 \%$ & $33.1 \%$ & $8.8 \%$ & $19.8 \%$ & $-1.6 \%$ & $9.4 \%$ & $-3.6 \%$ & $5.7 \%$ \\
\hline \multirow{7}{*}{ Mukherjee } & 0 & $70.6 \%$ & $73.7 \%$ & $64.5 \%$ & $64.5 \%$ & $26.4 \%$ & $26.4 \%$ & $24.6 \%$ & $25.6 \%$ & $8.8 \%$ & $10.7 \%$ \\
\hline & 15 & $89.1 \%$ & $93.9 \%$ & $91.8 \%$ & $93.5 \%$ & $42.6 \%$ & $42.6 \%$ & $25.2 \%$ & $25.2 \%$ & $17.9 \%$ & $17.9 \%$ \\
\hline & 30 & $62.7 \%$ & $68.2 \%$ & $83.1 \%$ & $83.7 \%$ & $32.9 \%$ & $32.9 \%$ & $24.0 \%$ & $24.0 \%$ & $21.4 \%$ & $22.2 \%$ \\
\hline & 45 & $62.1 \%$ & $78.9 \%$ & $55.4 \%$ & $55.9 \%$ & $39.1 \%$ & $39.1 \%$ & $31.2 \%$ & $31.2 \%$ & $25.6 \%$ & $25.6 \%$ \\
\hline & 60 & $27.4 \%$ & $41.0 \%$ & $33.7 \%$ & $35.3 \%$ & $21.9 \%$ & $21.9 \%$ & $23.0 \%$ & $23.0 \%$ & $22.2 \%$ & $23.3 \%$ \\
\hline & 75 & $26.7 \%$ & $46.5 \%$ & $33.5 \%$ & $35.0 \%$ & $17.4 \%$ & $18.0 \%$ & $17.8 \%$ & $18.0 \%$ & $22.9 \%$ & $22.9 \%$ \\
\hline & 90 & $15.9 \%$ & $30.4 \%$ & $27.2 \%$ & $30.3 \%$ & $17.0 \%$ & $19.1 \%$ & $16.7 \%$ & $17.5 \%$ & $19.8 \%$ & $19.8 \%$ \\
\hline \multirow{7}{*}{ Orkiszewski } & 0 & $-72.7 \%$ & $72.7 \%$ & $-71.2 \%$ & $71.2 \%$ & $-35.0 \%$ & $35.0 \%$ & $-30.1 \%$ & $30.1 \%$ & $-40.8 \%$ & $40.8 \%$ \\
\hline & 15 & $-72.7 \%$ & $72.7 \%$ & $-69.3 \%$ & $69.3 \%$ & $-36.0 \%$ & $36.0 \%$ & $-28.5 \%$ & $28.5 \%$ & $-36.3 \%$ & $36.3 \%$ \\
\hline & 30 & $-72.0 \%$ & $72.0 \%$ & $-68.1 \%$ & $68.1 \%$ & $-25.8 \%$ & $25.8 \%$ & $-26.6 \%$ & $26.6 \%$ & $-34.7 \%$ & $34.7 \%$ \\
\hline & 45 & $-71.4 \%$ & $71.4 \%$ & $-59.0 \%$ & $59.0 \%$ & $-30.1 \%$ & $30.1 \%$ & $-24.9 \%$ & $24.9 \%$ & $-32.5 \%$ & $32.5 \%$ \\
\hline & 60 & $-70.2 \%$ & $70.2 \%$ & $-59.8 \%$ & $59.8 \%$ & $-32.0 \%$ & $32.0 \%$ & $-23.5 \%$ & $23.5 \%$ & $-31.9 \%$ & $31.9 \%$ \\
\hline & 75 & $-68.2 \%$ & $68.2 \%$ & $-58.1 \%$ & $58.1 \%$ & $-24.0 \%$ & $24.0 \%$ & $-23.9 \%$ & $23.9 \%$ & $-30.8 \%$ & $30.8 \%$ \\
\hline & 90 & $-68.1 \%$ & $68.1 \%$ & $-53.1 \%$ & $53.1 \%$ & $-23.1 \%$ & $23.1 \%$ & $-22.7 \%$ & $22.7 \%$ & $-30.5 \%$ & $30.5 \%$ \\
\hline
\end{tabular}


Table 3. Basic data of X1 well

\begin{tabular}{|l|l|l|l|l|l|}
\hline Item & Unit & Value & Item & Unit & Value \\
\hline $\begin{array}{l}\text { Reservoir } \\
\text { depth }\end{array}$ & $\mathrm{m}$ & 2882 & $\begin{array}{l}\text { Wellhead } \\
\text { temperature }\end{array}$ & ${ }^{\circ} \mathrm{C}$ & 10 \\
\hline $\begin{array}{l}\text { Casing } \\
\text { depth }\end{array}$ & $\mathrm{m}$ & 3086 & $\begin{array}{l}\text { Bottom hole } \\
\text { temperature }\end{array}$ & ${ }^{\mathrm{C}}$ & 93.78 \\
\hline Casing size & in & $7+4-1 / 2$ & Water cut & $\%$ & 0 \\
\hline Tubing size & in & 3.5 & $\begin{array}{l}\text { Static } \\
\text { pressure }\end{array}$ & $\mathrm{MPa}$ & 30.66 \\
\hline Oil density & $\mathrm{g} / \mathrm{cm}^{3}$ & 0.793 & $\begin{array}{l}\text { Bubble } \\
\text { pressure }\end{array}$ & $\mathrm{MPa}$ & 19.07 \\
\hline $\begin{array}{l}\text { Natural gas } \\
\text { density }\end{array}$ & -- & 0.75 & $\begin{array}{l}\text { Formation } \\
\text { water } \\
\text { density }\end{array}$ & $\mathrm{g} / \mathrm{cm}^{3}$ & 1.02 \\
\hline $\begin{array}{l}\text { Produced } \\
\text { GOR }\end{array}$ & $\mathrm{m}^{3} / \mathrm{m}^{3}$ & 173.83 & $\begin{array}{l}\text { Wellhead } \\
\text { pressure }\end{array}$ & $\mathrm{MPa}$ & 3.1 \\
\hline
\end{tabular}

Table 4. Production measured data of X1 well

\begin{tabular}{|l|l|l|l|l|l|}
\hline $\begin{array}{l}\text { Choke } \\
\text { size } \\
\text { (in) }\end{array}$ & $\begin{array}{l}\text { Wellhead } \\
\text { tubing } \\
\text { pressure } \\
(\mathrm{MPa})\end{array}$ & $\begin{array}{l}\text { Bottom } \\
\text { flowing } \\
\text { pressure } \\
(\mathrm{MPa})\end{array}$ & $\begin{array}{l}\text { Liquid } \\
\text { rate } \\
\left(\mathrm{m}^{3} / \mathrm{d}\right)\end{array}$ & $\begin{array}{l}\text { Oil rate } \\
\left(\mathrm{m}^{3} / \mathrm{d}\right)\end{array}$ & $\begin{array}{l}\mathrm{GOR} \\
\left(\mathrm{m}^{3} / \mathrm{m}^{3}\right)\end{array}$ \\
\hline $48 / 64$ & 3.1 & 20.63 & 316.7 & 316.7 & 173.83 \\
\hline
\end{tabular}

Table 5. Basic data of $\mathrm{X} 2$ well

\begin{tabular}{|l|l|l|l|l|l|}
\hline Item & Unit & Value & Item & Unit & Value \\
\hline $\begin{array}{l}\text { Reservoir } \\
\text { depth }\end{array}$ & $\mathrm{m}$ & 2924 & $\begin{array}{l}\text { Wellhead } \\
\text { temperature }\end{array}$ & ${ }^{\circ} \mathrm{C}$ & 10 \\
\hline Casing depth & $\mathrm{m}$ & 2960 & $\begin{array}{l}\text { Bottom } \\
\text { hole } \\
\text { temperature }\end{array}$ & ${ }^{\circ} \mathrm{C}$ & 96.64 \\
\hline Casing size & in & $7+4-1 / 2$ & Water cut & $\%$ & 0 \\
\hline Tubing size & in & 3.5 & $\begin{array}{l}\text { Static } \\
\text { pressure }\end{array}$ & $\mathrm{MPa}$ & 29.26 \\
\hline Oil density & $\mathrm{g} / \mathrm{cm}^{3}$ & 0.82 & $\begin{array}{l}\text { Bubble } \\
\text { pressure }\end{array}$ & $\mathrm{MPa}$ & 19.07 \\
\hline $\begin{array}{l}\text { Natural gas } \\
\text { density }\end{array}$ & --- & 0.8 & $\begin{array}{l}\text { Formation } \\
\text { water } \\
\text { density }\end{array}$ & $\mathrm{g} / \mathrm{cm}^{3}$ & 1.01 \\
\hline $\begin{array}{l}\text { Produced } \\
\text { GOR }\end{array}$ & $\mathrm{m}^{3 / \mathrm{m}^{3}}$ & 157.62 & $\begin{array}{l}\text { Wellhead } \\
\text { pressure }\end{array}$ & $\mathrm{MPa}$ & 3.1 \\
\hline
\end{tabular}

Table 6. Production measured data of X2 well

\begin{tabular}{|l|l|l|l|l|l|}
\hline $\begin{array}{l}\text { Choke } \\
\text { size } \\
\text { (in) }\end{array}$ & $\begin{array}{l}\text { Wellhead } \\
\text { tubing } \\
\text { pressure } \\
(\mathrm{MPa})\end{array}$ & $\begin{array}{l}\text { Bottom } \\
\text { flowing } \\
\text { pressure } \\
(\mathrm{MPa})\end{array}$ & $\begin{array}{l}\text { Liquid } \\
\text { rate } \\
\left(\mathrm{m}^{3} / \mathrm{d}\right)\end{array}$ & $\begin{array}{l}\text { Oil rate } \\
\left(\mathrm{m}^{3} / \mathrm{d}\right)\end{array}$ & $\begin{array}{l}\mathrm{GOR} \\
\left(\mathrm{m}^{3} / \mathrm{m}^{3}\right)\end{array}$ \\
\hline $40 / 64$ & 3.1 & 22.2 & 251.19 & 251.19 & 157.62 \\
\hline
\end{tabular}

Table 7. Basic data of X3 well

\begin{tabular}{|l|l|l|l|l|l|}
\hline Item & Unit & Value & Item & Unit & $\begin{array}{l}\text { Valu } \\
\mathrm{e}\end{array}$ \\
\hline $\begin{array}{l}\text { Reservoir } \\
\text { depth }\end{array}$ & $\mathrm{m}$ & 3028 & $\begin{array}{l}\text { Wellhead } \\
\text { temperature }\end{array}$ & ${ }^{\circ} \mathrm{C}$ & 10 \\
\hline $\begin{array}{l}\text { Casing } \\
\text { depth }\end{array}$ & $\mathrm{m}$ & 3140 & $\begin{array}{l}\text { Bottom hole } \\
\text { temperature }\end{array}$ & ${ }^{\circ} \mathrm{C}$ & 95.41 \\
\hline Casing size & in & $7+4-1 / 2$ & Water cut & $\%$ & 0 \\
\hline $\begin{array}{l}\text { Tubing } \\
\text { size }\end{array}$ & in & 3.5 & $\begin{array}{l}\text { Static } \\
\text { pressure }\end{array}$ & $\begin{array}{l}\text { MP } \\
\mathrm{a}\end{array}$ & 27.89 \\
\hline $\begin{array}{l}\text { Oil density } \\
\mathrm{g} / \mathrm{cm}^{3}\end{array}$ & 0.82 & $\begin{array}{l}\text { Bubble } \\
\text { pressure }\end{array}$ & $\begin{array}{l}\mathrm{MP} \\
\mathrm{a}\end{array}$ & 17.2 \\
\hline $\begin{array}{l}\text { Natural gas } \\
\text { density }\end{array}$ & --- & 0.8 & $\begin{array}{l}\text { Formation } \\
\text { water density }\end{array}$ & $\begin{array}{l}\mathrm{g} / \mathrm{c} \\
\mathrm{m}\end{array}$ & 1.01 \\
\hline $\begin{array}{l}\text { Produced } \\
\text { GOR }\end{array}$ & $\mathrm{m}^{3} / \mathrm{m}^{3}$ & 101.7 & $\begin{array}{l}\text { Wellhead } \\
\text { pressure }\end{array}$ & $\begin{array}{l}\mathrm{MP} \\
\mathrm{a}\end{array}$ & 4.79 \\
\hline
\end{tabular}

Table 8. Production measured data of $\mathrm{X} 3$ well

\begin{tabular}{|l|l|l|l|l|l|}
\hline $\begin{array}{l}\text { Choke } \\
\text { size } \\
\text { (in) }\end{array}$ & $\begin{array}{l}\text { Wellhead } \\
\text { tubing } \\
\text { pressure } \\
(\mathrm{MPa})\end{array}$ & $\begin{array}{l}\text { Bottom } \\
\text { flowing } \\
\text { pressure } \\
(\mathrm{MPa})\end{array}$ & $\begin{array}{l}\text { Liquid } \\
\text { rate } \\
\left(\mathrm{m}^{3} / \mathrm{d}\right)\end{array}$ & $\begin{array}{l}\text { Oil rate } \\
\left(\mathrm{m}^{3} / \mathrm{d}\right)\end{array}$ & $\begin{array}{l}\text { GOR } \\
\left(\mathrm{m}^{3} / \mathrm{m}^{3}\right)\end{array}$ \\
\hline $48 / 64$ & 4.79 & 26.43 & 688.87 & 4333 & 101.7 \\
\hline
\end{tabular}

Table 9. Basic data of X4 well

\begin{tabular}{|l|l|l|l|l|l|}
\hline Item & Unit & Value & Item & Unit & Value \\
\hline $\begin{array}{l}\text { Reservoir } \\
\text { depth }\end{array}$ & $\mathrm{m}$ & 2700 & $\begin{array}{l}\text { Wellhead } \\
\text { temperature }\end{array}$ & ${ }^{\circ} \mathrm{C}$ & 10 \\
\hline $\begin{array}{l}\text { Casing } \\
\text { depth }\end{array}$ & $\mathrm{m}$ & 2810 & $\begin{array}{l}\text { Bottom hole } \\
\text { temperature }\end{array}$ & ${ }^{\circ} \mathrm{C}$ & 96.1 \\
\hline Casing size & in & 7 & Water cut & $\%$ & 0 \\
\hline Tubing size & in & 3.5 & Static pressure & $\mathrm{MPa}$ & 32.75 \\
\hline Oil density & $\mathrm{g} / \mathrm{cm}^{3}$ & 0.93 & $\begin{array}{l}\text { Bubble } \\
\text { pressure }\end{array}$ & $\mathrm{MPa}$ & 11.52 \\
\hline $\begin{array}{l}\text { Natural gas } \\
\text { density }\end{array}$ & --- & 1.13 & $\begin{array}{l}\text { Formation } \\
\text { water density }\end{array}$ & $\begin{array}{l}\mathrm{g} / \mathrm{cm} \\
3\end{array}$ & 1.02 \\
\hline $\begin{array}{l}\text { Produced } \\
\text { GOR }\end{array}$ & $\mathrm{m}^{3} / \mathrm{m}^{3}$ & 67.68 & $\begin{array}{l}\text { Wellhead } \\
\text { pressure }\end{array}$ & $\mathrm{MPa}$ & 5.19 \\
\hline
\end{tabular}

Table 10. Production measured data of X4 well

\begin{tabular}{|l|l|l|l|l|l|}
\hline $\begin{array}{l}\text { Choke } \\
\text { size(in) }\end{array}$ & $\begin{array}{l}\text { Wellhead } \\
\text { tubing } \\
\text { pressure } \\
(\mathrm{MPa})\end{array}$ & $\begin{array}{l}\text { Bottom } \\
\text { flowing } \\
\text { pressure } \\
(\mathrm{MPa})\end{array}$ & $\begin{array}{l}\text { Liquid } \\
\text { rate } \\
\left(\mathrm{m}^{3} / \mathrm{d}\right)\end{array}$ & $\begin{array}{l}\text { Oil } \\
\text { rate } \\
\left(\mathrm{m}^{3} / \mathrm{d}\right)\end{array}$ & $\begin{array}{l}\mathrm{GO} \\
\left(\mathrm{m}^{3} / \mathrm{m}^{3}\right)\end{array}$ \\
\hline & 5.19 & 26.7 & 349.8 & 349.8 & 67.68 \\
\hline
\end{tabular}






Figure 9. Calculation results comparison of multiphase flow pressure calculation methods for X1 well

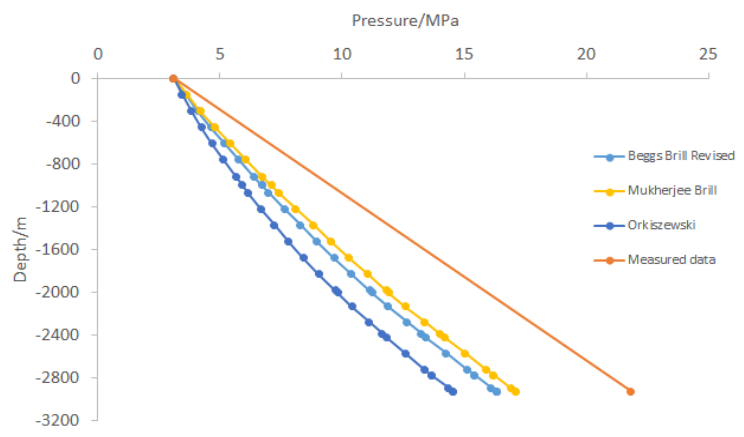

Figure 10. Calculation results comparison of multiphase flow pressure calculation methods for X2 well

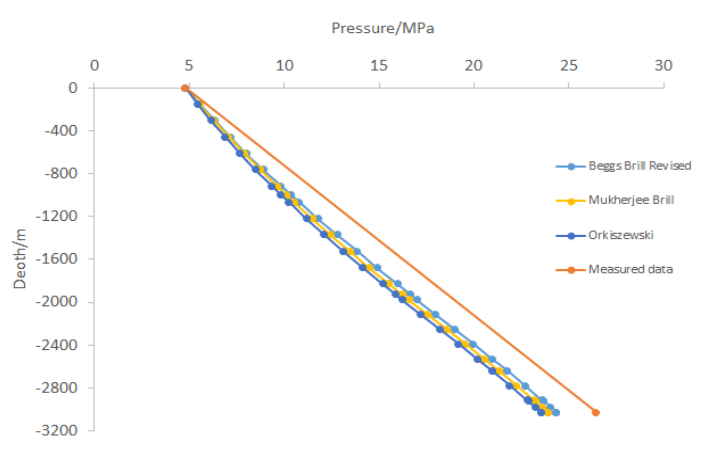

Figure 11. Calculation results comparison of multiphase flow pressure calculation methods for X1 well

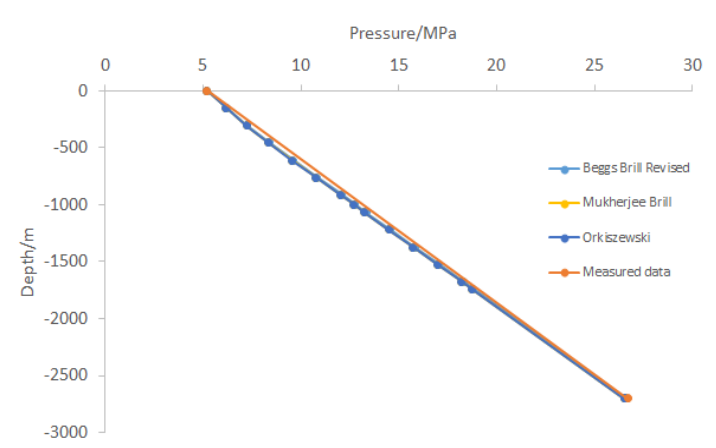

Figure 12. Calculation results comparison of multiphase flow pressure calculation methods for X2 well

\section{CONCLUSIONS}

Flow law of gas-liquid two-phase flow can solve the problem of the fluid flow in the oil industry, aerospace, chemical and other industries. Experimental research of inclined tube gas liquid two phase flow for high flow rate was conducted in Yangtze University multiphase flow experimental platform. The following conclusions can be obtained through analysis of the experimental data and validation of multiphase pipe flow pressure calculation methods by both experimental data and the oilfield measured data:

(1) At the same liquid flow rate, liquid holdup decreased as the gas flow rate increased. At small gas flow velocity, liquid holdup decreased quickly as the gas flow velocity increased. Liquid holdup decreased slowly as the gas flow velocity increased to a certain value. Liquid holdup tended to be stable.

(2) At the same gas flow velocity condition, liquid holdup and pressure drop increased as the of liquid flow velocity increased. At the same liquid flow velocity condition, when liquid velocity is larger $(1.228 \sim 1.965 \mathrm{~m} / \mathrm{s})$, pressure drop increased quickly at first as the gas flow velocity increased, and then increased slowly. At a small liquid flow velocity $(0.205 \sim 1.023 \mathrm{~m} / \mathrm{s})$, pressure drop increased slowly at first as the gas flow velocity increased, or it decreased slightly and then increased quickly.

(3) Liquid holdup increased at first on the whole as the inclined angle increased, and then had a decreasing trend, and the liquid holdup is largest in the angle range of $30^{\circ}$ to $60^{\circ}$. Pressure drop increased the fastest in the angle range of $30^{\circ}$ to $60^{\circ}$, and it is in agreement with liquid holdup variation law as the inclined angle increases.

(4) When the inclination angle is less than or equal to $45^{\circ}$ and the production rate is less than or equal to $200 \mathrm{~m} 3 / \mathrm{d}$, liquid holdup calculation error of Beggs Brill revised is greater than that of Brill-Mukherjee. In other remaining conditions, liquid holdup calculation error of Beggs Brill revised was less than that of Brill-Mukherjee. As can be seen from the liquid holdup calculation error of Beggs Brill revised, the liquid holdup calculation error decreases as the production rate increases. At the same time, the liquid holdup calculation error decreases as the inclined angle increases.

(5) Experimental data validation shows that for three kinds of calculation methods, the average calculation error of Beggs Brill revised pressure drop calculation method is the lowest. The average calculation error of three pressure drop calculation methods mostly had a decreasing trend as the inclined angle increased. At the same time, most of average calculation error of the three pressure drop calculation methods showed a decreasing trend as the production rate increased.

(6) Oilfield data validation shows that the order of size of prediction results of three kinds of multiphase flow pressure calculation methods using the oilfield measured parameters is mostly the same as the order of size of prediction results of these methods using the experimental parameters. Prediction results of three kinds of multiphase flow pressure prediction methods using the oilfield measured parameters were all smaller than the oilfield measured data, and their prediction error is the same as the trend of prediction error of three kinds of calculation methods using experimental parameters, the trend is that prediction error decreases and pressure drop prediction results changed from larger to smaller than experimental data as the production rate increases. 
In short, at a high production rate, predicting pressure drop using the existing calculation methods was lower than measured data, and pressure drop prediction method of Beggs Brill revised is the best of the existing methods.

\section{ACKNOWLEDGMENT}

The authors would like to acknowledge the National Natural Science Fund Project (61572084) and CNPC special fund for key project. And thanks for Ruiquan Liao of the corresponding author for the article.

\section{REFERENCES}

[1] Duns, H., \& Ros, N. C. J. (1963). Vertical flow of gas and liquid mixtures in wells. Presented at 6th World Petroleum Congress. Available: https://www.onepetro.org/conference-paper/WPC10132

[2] Hagedorn, A. R., \& Brown, K. E. (1965). Experimental study of pressure gradients occurring during continuous two-phase flow in small-diameter vertical conduits. Journal of Petroleum Technology, 17(4), pp. 475-484. Available: https://www.onepetro.org/journal-paper/SPE-940-PA

[3] Orkiszewski, J. (1967). Predicting two-phase pressure drops in vertical pipe. Journal of Petroleum Technology, 19(6), pp. 829-838. Available: https://www.onepetro.org/journal-paper/SPE-1546-PA

[4] Aziz, K., \& Govier, G. W. (1972). Pressure drop in wells producing oil and gas. Journal of Canadian Petroleum Technology, 11(3), pp. 38-48. Available: http://dx.doi.org/10.2118/72-03-04

[5] Taitel, Y., Bornea, D. and Dukler, A. E. (1980), Modelling flow pattern transitions for steady upward gas-liquid flow in vertical tubes. AIChE J., 26: 345354. DOI: $10.1002 /$ aic.690260304.

[6] Hasan, A. R., \& Kabir, C. S. (1986). A Study of Multiphase Flow Behavior in Vertical Oil Wells: Part I - Theoretical Treatment. Presented at SPE California Regional Meeting. Available: http://dx.doi.org/10.2118/15138-MS

[7] Liao, R., Wang Qisheng, \& Zhang Bainian. (1998). A method for predicting vertical multiphase flow pressure gradient in vertical wellbore. Journal of Jianghan Petroleum Institute, 20(1), pp. 59-63. Available:

http://en.cnki.com.cn/Article_en/CJFDTotalJHSX801.012.htm

[8] Graba, B., Boukadida, N., \& Sassi, M. (2004). Heat and mass transfer in turbulent flow inside an horizontal channel. International Journal of Heat \& Technology, 22(2), pp. 13-21.

[9] Graba, B., \& Boukadida, N. (2006). Effect of radiation and turbulence on forced convection flow inside a rectangular channel: validity of heat and mass transfer analogy and inversion temperature. International Journal of Heat \& Technology, 24(2), pp. 43-51.

[10] Beggs, D. H., \& Brill, J. P. (1973). A study of twophase flow in inclined pipes. Journal of Petroleum Technology, 25(5), pp. 607-617. DOI: 10.2118/4007$\underline{\text { PA. }}$
[11] Zhang qi etc., "Calculation of oil well inflow performance and multiphase flow in wellbore," in Principle and design of oil production engineering, Dongying City, Shandong Province, China: China petroleum university press, 2006, pp.86-88.

[12] Kokal, S. L., \& Stanislav, J. F. (1989). An experimental study of two-phase flow in slightly inclined pipes-i. flow patterns. Chemical Engineering Science, 44(3), pp. 665-679. DOI: 10.1016/0009-2509(89)85042-0.

[13] Wang J, Jia Z H, et al. (2005). Study of the flow patterns propagation behavior of oil-gas two-phase flow in the large diameter pipes. Journal of Engineering Thermophysics. 26(S1), pp. 137-139. Available:

http://en.cnki.com.cn/Article_en/CJFDTotalGCRB2005S1035.htm

[14] Cai, J. Y. (1999). Investigation of flow regime transitions in large-diameter inclined pipes. Journal of Energy Resources Technology, 121(2), pp. 91-95. Available:

http://energyresources.asmedigitalcollection.asme.org/ article.aspx?articleID $=1413814$

[15] Oddie, G., Shi, H., Durlofsky, L. J., Aziz, K., Pfeffer, B., \& Holmes, J. A. (2003). Experimental study of two and three phase flows in large diameter inclined pipes. International Journal of Multiphase Flow, 29(4), pp. 527-558. DOI: 10.1016/S03019322(03)00015-6.

[16] Perez V H., "Gas-liquid two-phase flow in inclined pipes," Ph.D. dissertation. University of Nottingham, Britain, 2008. Available: https://core.ac.uk/download/pdf/18110.pdf

[17] Liao, R., Yong, L. I., Song, J., \& Lei, Y. (2014). The establishment of multiphase flow experiment platform in gas lift test base. Journal of Oil \& Gas Technology, pp.129-131.

http://en.cnki.com.cn/Article en/CJFDTotalJHSX201409028.htm

[18] Mukherjee, H., \& Brill, J. P. (1985). Pressure drop correlations for inclined two-phase flow. Journal of Energy Resources Technology, 107(4), pp.549-554. Available:

http://energyresources.asmedigitalcollection.asme.org/ article.aspx? articleid $=1412605$

[19] Ansari, A. M., Sylvester N.D., Sarica C., Shoham O., Brill J.P. (1994). A comprehensive mechanistic model for upward two-phase flow in wellbores. Spe Production \& Facilities, 2(2), pp.143-151. Available: https://www.onepetro.org/journal-paper/SPE-20630$\underline{\mathrm{PA}}$

[20] Zhang, H. Q., Wang, Q., Sarica, C., \& Brill, J. P. (2003). A unified mechanistic model for slug liquid holdup and transition between slug and dispersed bubble flows. International Journal of Multiphase Flow, 29(1), pp.97-107. DOI: $10.1016 / \mathrm{S} 0301-$ 9322(02)00111-8.

\section{NOMENCLATURE}

$\mathrm{dp}$

$\mathrm{dz}$ differential pressure drop, $\mathrm{Pa}$ infinitesimal length, $\mathrm{m}$ 
Subscripts

total

gravity total pressure drop of unit length, $\mathrm{Pa}$ gravity pressure drop of unit length, $\mathrm{Pa}$ friction

acceleration friction pressure drop of unit length, $\mathrm{Pa}$ acceleration pressure drop of unit length, $\mathrm{Pa}$ 